\title{
Sosyal Sermaye ve Bölgesel Kalkınma Iliş̧kisi: Aksaray Örneği
}

\section{The Relationship between Social Capital and Regional Development: The Case of Aksaray}

\author{
İlknur KARATAŞ, İsmail SEKi ${ }^{1}$
}

\begin{abstract}
ÖZET
$\mathrm{Bu}$ çalışmada son yıllarda sosyal bilimciler tarafından sıkça kullanılan sosyal sermaye kavramı ve bölgesel ekonomik kalkınmada sosyal sermayenin önemi açıklanmaya çalışılmışır. Bu maksatla, sosyal sermaye düzeyinin ölçülmesi ve bu düzeyi belirleyen sosyal sermaye göstergelerinin belirtildiği Aksaray İli ve ilçelerinde uygulanan anket çalışması yer almaktadır. Saha çalışmasına göre, güven, network, karşılıklı yardımlaşma ve ortak işbirliği endeksleri genel olarak değerlendirildiğinde Aksaray'da sosyal sermaye düzeyinin ve dolayısıla kalkınma oranlarının düşük olduğunu söylemek mümkündür. Komşusu olduğu illerin kalkınma düzeyleri daha yüksek olmasına rağmen Aksaray'ın düşük seviyelerde kalmasını önlemek ve gelişmişlik seviyesini artırmak için, öncelikle beşeri ve sosyal sermayenin geliştirilmesi başııca hedef olmalıdır.
\end{abstract}

Anahtar kelimeler: Sosyal Sermaye, Bölgesel Kalkınma, Sosyal Sermaye Endeksi

\section{GíRiş}

Küreselleşme olgusu ile birlikte dünyadaki üretim kalıpları ve uygulanan ekonomi politikaları da değişmektedir. Bu bağlamda sanayi toplumunda temel üretim faktörü olan fiziki ve mali sermaye birikimi ön planda iken, bilgi toplumunda beşeri ve sosyal sermaye birikiminin ön planda olduğu görülmektedir. Son dönemlerde gündemde önemli bir yer tutan sosyal sermaye kavramının, sosyal ve bölgesel kalkınmanın sağlanmasında önemli bir araç olduğu sıklıkla gündeme getirilmektedir. Sosyal sermaye; bir ülkede kişi ve kurumlar arası dürüstlük, güven unsuru, bilgi paylaşımı, ortak hareket etme, sosyal dayanışma gibi dikey ve yatay karakterli ilişkileri göstermektedir.

Sosyal sermaye kavramı daha çok son yıllarda önem kazanmış; özellikle ekonomik ve toplumsal alandaki önemi ve etkinliği ile dikkat çeken bir

\begin{abstract}
The study tries to explain social capital term and the importance of social capital in regional development. For this purpose, there is an empirical analyses based on survey for Aksaray City that calculates the level of social capital and determines the indicators of social capital. According to the fieldwork, while trust, network, reciprocal assistance and cooperation indexes are interpreted, social capital and regional development level of Aksaray are low. Although the development levels of neighbor cities are high, it is need to improve the human and social capital levels of Aksaray.
\end{abstract}

Keywords: Social Capital, Regional Development, Social Capital Index olgudur. Son yılların en önemli ekonomik ve sosyal kavramlarından olan sosyal sermaye olgusu, ülkelerin ekonomik, siyasi ve sosyal alanlardaki başarılarıyla doğrudan ilgili bir faktör olarak değerlendirilmektedir (Woodhouse, 2006: 84). Söz konusu kavramın tek bir tanımını yapmak oldukça zordur. Çünkü gerek sosyologlar, gerekse kavramın gelişmesi ile birlikte günümüzde sosyal sermaye üzerine çalışan bilim adamları, sosyal sermayeyi farklı biçimlerde tanımlamaktadırlar. Tanımlama farklılıklarının oluşması, kavramın farklı yönlerine farklı düzeylerde vurgu yapılmasından kaynaklanmaktadır.

Çalışmanın ikinci bölümünde literatür özetine yer verilmiş, üçüncü bölümde sosyal sermaye kavramı açıklanmış, dördüncü bölümde sosyal sermaye ile bölgesel kalkınma arasındaki bağlantılar ortaya konmaya çalışılmış, beşinci bölümde Aksaray ili özelinde sosyal sermaye endeksine ilişkin ampirik 
bir analiz yapılmış, altıncı ve son bölümde sonuç ve değerlendirmelere yer verilmiştir.

\section{KAVRAMSAL ÇERÇEVE}

Sosyal sermayeye ilişkin uluslararası literatür nispeten zengin sayılsa da maalesef ulusal alandaki çalışmalar için aynı durum söz konusu değildir'.

\subsection{Sosyal Sermaye Kavramı}

Sosyal sermaye kavramını ilk ortaya atan kişilerden olan eğitimci Hanifan (1916) sosyal sermayenin insanların günlük yaşantısında önemi olan somut maddelerden ziyade; iyi niyet, arkadaşlık, sempati ve sosyal birlikteliği meydana getiren, bireyler ve aileler arasındaki sosyal ilişkiler olduğunu belirtmektedir. Robert Putnam, günümüzde sosyal sermaye ile ilgili hemen hemen tüm teorikve uygulamalı araştırmaların en çok başvuru kaynağıdır. Putnam (2000), sosyal sermayeyi; "bireyler arasındaki ilişkiler, sosyal ağlar ve bunlardan meydana gelen karşılıklılık ve güvenilirlik normları" şeklinde tanımlayarak, kavramın temel özelliğinin yatay ağlar olduğunu vurgulamaktadır. Sosyal sermaye kavramının şekillenmesinde en fazla katkıyı yapan kişilerden biri de James Coleman'dır. Coleman (1988)'e göre sosyal sermaye, "tek başına bir varlık değil, ortak özellikleri olan farklı varlıkların bir kümesidir. Bunlar sosyal yapının bazı yönlerini oluşturmakta ve yapı içindeki ortak aktörlerin veya bireylerin eylemlerini kolaylaştırmaktadır". Ona göre sosyal sermaye bireyler arasındaki ilişkilerin yapısından kaynaklanmaktadır.

Siyasal bilimler, iktisat ve sosyoloji gibi birçok sosyal bilimin alanına doğrudan giren sosyal sermaye olgusu varlık temelli bölgesel kalkınma paradigmaları gibi yeni yaklaşımlarda da açıklayıcı bir değişken olarak kendine yer bulabilir.

Velibeyoğlu (2009)'a göre varlık temelli ekonomik gelişme, kalkınması hedeflenen bölgedeki insanların yaşam kalitelerini artıracak bölgesel ekonomik geri dönüşleri oluşturacak ortamı meydana getirmelidir. Söz konusu yaklaşım bu yönüyle Florida (2005) tarafından ortaya konan yaratıcı ekonomi yaklaşımı ile paralellik göstermektedir.

\subsection{Sosyal Sermaye ve Bölgesel Kalkınma iliş̧kisi}

Son zamanlarda bölgesel kalkınma anlayışındaki varlık temelli kalkınma politikalarını esas alan paradigma değişimlerine paralelolaraksosyal sermaye konusu hem ekonomi alanında hem de sosyal alanda oldukça popüler olmuştur (Velibeyoğlu, 2009: 4243). Ülkeler arasındaki ya da ülkede coğrafi bölgeler arasındaki eşitsizliklerin ve gelişmişlik farklılıklarının giderilmesindeki politikaların belirlenmesinde diğer sermaye türleri ile birlikte sosyal sermaye de çokça kullanılmaktadır. Sosyal sermaye kavramının doğası gereği mikro düzeyde etkileri makro düzeydeki etkilerinden daha baskındır. Sosyal sermayenin bölgesel kalkınma üzerindeki etkileri, ulusal kalkınma üzerindeki etkileri ile paralellik göstermekle beraber bölgesel düzeyde daha baskındır.

Sosyal sermaye olgusunun bölgesel kalkınmaya olan doğrudan etkileri altı alt başlıkta toparlanabilir. Bunlar maliyet üzerine etkisi, yatırım üzerine etkisi, gelir dağılımı üzerine etkisi, verimlilik üzerine etkisi, etkinlik üzerine etkisi ve girişimcilik üzerine etkisidir.

\subsubsection{Sosyal Sermayenin Maliyetler Üzerine Etkisi}

Sosyal sermayenin ekonomik maliyetleri düşürücü bir etkisi bulunmaktadır. Söz konusu etki ile sosyal sermayesi yüksek olan bölgelerde maliyetlerin düşmesi bununla birlikte ekonomik büyüme ve kalkınmanın artması beklenmektedir. Sosyal sermaye bölgedeki ekonomik aktörler arasındaki ortak faaliyet problemlerinin çözümünü kolaylaştırarak işlem maliyetlerinin düşmesini sağlar. Sosyal sermayenin maliyetler üzerindeki bir başka pozitif etkisi ise emek, sermaye ve zaman israfına neden olan birçok işlemden tasarruf edilmesini sağlamasıdır. Bu maliyet düşüşünde güvenin ve gelişsmiş iletişim imkânlarının sosyal sermaye ile artırılması etkilidir. Ayrıca sosyal sermayenin en önemli bileşenlerinden olan güven düzeyinin yükselmesi bölgedeki suç ve suça bağlı maliyetlerin azalmasını sağlayarak bu alana ayrılan kaynakların üretime yönlendirilmesiyle birlikte bölgesel kalkınmaya pozitif katkı sunmaktadır (Tüysüz 2011: 33; Woolcock 2000: 236).

Fukuyama (2005)'e göre çağdaş dünyada tüm ekonomik faaliyetler bireysel çalışmalardan ziyade, yüksek düzeyli sosyal işbirliği içeren sosyal organizasyonlar tarafından başarılmaktadır. Pazar ekonomisinin temelini oluşturan mülkiyet hakları, sözleşmeler ve ticari yasaların hepsi eğer güvenle birleşirse işlem maliyetleri önemli ölçüde düşürülebilecektir. Bunu başarmanın yolu ise yüksek 
sosyal sermayeye sahip olmaktır. Bir toplum ya da devlet, sosyal sermaye konusunda sağlam bir ilerleme kaydedebilirse ekonomik anlamda da yüksek bir başarıya ulaşacaktır.

\subsubsection{Sosyal Sermayenin Yatırımlar Üzerine Etkisi}

Bölgelerde suç oranlarının düşmesi, güven ortamının sağlanmış olması, siyasi istikrarın bulunması bölgeye yatırım yapılabilir bir nitelik sağlamaktadır. Söz konusu özelliklerin tümü sosyal sermaye oranı yüksek bölgelerde diğer bölgelere oranla da fazla bulunmaktadır (Schaik 2002: 9). Bu nedenle sosyal sermaye oranı yüksek olan bölgeler rakiplerine oranla daha fazla yatırım çekebilirler. Daha fazla yatırım yapılan bölgeler gerek ekonomik büyüme gerekse de ekonomik kalkınma bakımından rakiplerinden daha öndedirler.

\subsubsection{Sosyal Sermayenin Gelir Dağılımı Üzerine Etkisi}

Bölgedeki sosyal sermaye miktarı ile gelir dağılımı-denetim mekanizmalarının işlemesi ve nepotizm (akraba/üye kayırma) olmaması durumunda-arasında pozitif bir ilişkiden söz edilebilir. Özellikle ülkemizdeki gibi bölgesel riskleri yönetebilecek kurumsal yönetişim mekanizmalarının olmaması durumunda karşılıklı yardımlaşma daha da önemli olmaktadır (Callois, Aubert 2005: 3-4). Sosyal sermayenin yüksek olduğu bölgelerde diğerlerine göre karşılıklı yardımlaşmanın daha fazla görülmesi beklenmektedir. Bu durum riskleri minimize ederken, gayri resmi bir sigorta işlevi görerek gelir dağılımındaki adaletsizliği azaltıı bir unsur oluşturmaktadır.

\subsubsection{Sosyal Sermayenin Verimlilik Üzerine Etkisi}

Sosyal sermaye ile verimlilik arasında pozitif bir ilişki söz konusudur. Sosyal sermayesi yüksek olan bölgelerde beşeri sermaye kalitesi diğerlerine göre daha yüksektir. Hem sağlık hem de eğitim bakımından daha üstün olan beşeri sermayeye sahip bölgelerde emeğin verimliliği rakiplerine oranla daha fazla olacaktır (Eşki 2009: 80-81). Verimlilik artışının ekonomik büyümenin anahtarı olduğu günümüz ekonomilerinde, sosyal sermayesi yüksek olan ve dolayısıyla emek verimliliği artışında rakiplerini geride bırakan bölgelerin bölgesel kalkınma süreçlerinde rakiplerinden önde olacağı aşikârdır.

\subsubsection{Sosyal Sermayenin Etkinlik Üzerine Etkisi}

Sosyal sermayenin ekonomik etkinlik ile ilişkisi hem pozitif hem de negatif yönlüdür. Pozitif yönlü ilişkinin temelinde sosyal sermayesi yüksek olan bölgelerde kaynak israfının az olması yatmaktadır. Sosyal sermayenin yüksek olması söz konusu bölgelerde toplumsal demokrasinin yerleşmesini sağlayarak kötü yönetimden kaynaklanan kaynak israfının önüne geçmektedir (Tüysüz 2011:33). Ancak söz konusu bölgelerde sosyal sermaye ağları dışında kalan ekonomik aktörler için negatif etkiler de söz konusudur. Bazı durumlarda sosyal sermaye ağlarına üye olanlar lehine ve adı geçen ağlara üye olmayan ekonomik aktörler aleyhine işleyen bir etkinsizlik durumu ortaya çıkabilir. Bu etkinsizlik durumu özellikle kaynak dağılımında etkinsizlik olarak ortaya çıkar (Portes, Landolt 2000: 552 - 553). Adı geçen ağlara üye olanlar arasında bireysel veya kurumsal düzeyde nepotizm oluşması durumunda ekonomik aktörlerin özellikle yönetim kısmındaki şeffaflık ortadan kalkar ve hem üretim, hem yönetim hem de kaynaklara erişim konusunda etkinsizlik meydana gelir (Woolcock 2001: 68). Bu durum gelir dağılımında adaletsizliğe de neden olmaktadır.

Yukarıda açıklanan negatif etkilere ülkemiz için verilebilecek iki örnek aile şirketleri ile sosyal yardımlara erişilebilirliktir. Aile şirketlerinin kurumsallaşamamasının önündeki en önemli etken, şirket sahiplerinin aile dışındaki kimseye yönetim yetkisi verecek kadar güvenmemesidir. Bu durum şirketlerin kurumsallaşması ve şirket kaynaklarının etkin kullanılması önündeki engellerin başında gelmektedir. İkinci durumda ise kıt olan sosyal yardımların dağıtıımasında yardımların gönderileceği kişileri belirleyen (sosyal yardım görevlisi, muhtar gibi) yetkililer ile yakın ilişkisi bulunan yani aynı sosyal sermaye ağına üye olan kişilerin öncelikli bir konum kazanmasını söz konusudur.

\subsubsection{Sosyal Sermayenin Yenilik Üzerine Etkisi}

Günümüz kapitalist ekonomik sistemin itici motorlarından olan yeniliğe dayalı girişimcilik ruhunun ortaya çıkabilmesi için gereken ortamın sağlamasında bölgenin sosyal sermaye düzeyi büyük önem teşkil eder. Bir bölgenin sosyal sermaye seviyesi artıkça yeniliklerin toplum içinde yayılması ve yenilikçiliğin teşvik edilmesi daha da kolaylaşır (Tüysüz 2011: 33). Yeniliğe dayalı bölgesel kalkınma stratejilerinin işleyebilmesi için bölgenin zengin 
bir sosyal sermaye stokuna sahip olması gerekir. Bunun nedeni bir icat veya yeniliğin kabul edilmesi, benimsenmesi ve yayılmasının sosyal sermayesi yüksek olan bölgelerde diğerlerine göre daha kolay olmasıdır. Bu durum sosyal sermaye bakımından zengin olan bölgenin diğerlerine oranla daha hızlı ve daha yüksek ölçekte bir teknolojik ilerleme yaşaması imkânına sahip olması anlamına gelmektedir (lyer, vd. 2005: 1017). Yüksek teknolojik ilerleme potansiyeli bölgenin sadece girişimcilik değil aynı zamanda verimliliğini de artıran bir unsurdur.

Bir bölgede sosyal sermaye bileşenlerinden sivil ağ bağlantılarının diğer bileşenlerden daha fazla ön planda olması bölgenin muhafazakârlık seviyesini artırarak yenilikçilik potansiyeline negatif etki edebilir. Söz konusu bölgeye has bazı gelenek ve normlar yeniliklere karşı toplumsal bir direnç oluşmasına neden olabilir (Knowles 2005: 14). Bu durum bölgenin hem girişimcilik hem de yenilikçilik potansiyelini düşürmesi açısından bölgesel kalkınmayı yavaşlatır. Sosyal sermaye olgusunu oluşturan güven, resmi ve gayri resmi sosyal ağlara üyelik, karşılıklı yardımlaşma ve işbirliği öğelerinin eşanlı olarak geliştirilmemesi veya yeterli denetim mekanizmalarının oluşturulmaması bahsi geçen negatif etkilerin oluşmasının en önemli nedenidir.

Sosyal sermaye konusunda yapılan çalışmalar ve sosyal sermaye düzeyini ölçmeye yönelik uygulamalı araştırmaların birçoğu sosyal sermayenin toplumsal düzen ve ekonomik kalkınma üzerinde pozitif katkısının olduğu izlenimi uyandırmaktadır. Ülkeler açısından baktığımızda; sosyal sermayesi yüksek olan toplumların daha kolay kalkındığı, kamu bürokrasisinin daha iyi çalıştığı, demokrasinin daha fazla yerleştiği ve insanların yaşam standartlarının daha iyi olduğu görülmektedir.

\section{SOSYAL SERMAYE ve BÖLGESEL KALKINMA ILIŞKISININ ANALIZi: AKSARAY ILIi ÜZERINE BİR UYGULAMA}

Türkiye'nin merkezinde yer alarak; batıyı - doğuya, kuzeyi - güneye bağlayarak karayolu ticaretinde önemli bir konuma sahip olan Aksaray ilinin ekonomik ve sosyal yapısındaki iyileşmeler dikkat çekmektedir. Aksaray; özellikle son yıllarda yeni sanayi kuruluşlarının açıldığı ve ticaret hacminin geliştiği bir il olmuştur. Sosyal sermayenin bölgesel kalkınmada rolü ve önemi göz önüne alındığında Aksaray'daki mevcut sosyal sermaye düzeyinin belirlenmesi önem arz etmektedir.

\subsection{Araştırmanın Yöntemi}

Araştırma, Aksarayilimerkezindeve Aksaray'abağlı bulunan ilçelerde ikamet eden bireylerden oluşan bir örnek kütle üzerinde anket yöntemine dayalı bir saha araştırması gerçekleştirmeyi hedeflemiştir. Bu evren içerisinde örneklem büyüklügünü belirlemek amacıyla Erdoğan'ın (2003: 440) hazırladığı tablodan yararlanılmıştır. Buna göre Aksaray ili merkezinde güven düzeyi $\% 95$, örneklem hatası $\mathrm{H}=+-0,05$ ve oranlar $p=0,5$ ve $q=0,5$ için örneklem büyüklüğü 662 olmalıdır. Merkez için, bu güven aralığında yaklaşık 700 kişiye anket dağıtılması uygun görülmüştür. Illçelerin belirlenmesinde coğrafi olarak yakın oldukları iller ve merkeze uzaklıkları etkili olmuştur. Bu amaçla kuzeyde Ankara iline yakın olan Ortaköy İlçesi, güneyde Niğde iline yakın olan Güzelyurt ilçesi, doğuda Kayseri iline yakın olan Gülağaç ilçesi ve batıda Konya iline yakın olan Eskil ilçesi örnek kütlenin uygulanacağı yerler olarak seçilmiştir. ilç̧elerin Aksaray merkeze olan uzaklıkları ise sırayla; Gülağaç 33 km., Güzelyurt 38 km., Ortaköy 50 km. ve Eskil $71 \mathrm{~km}$. dir. İlçelerde örneklem büyüklüğü nüfus oranlarına göre yaklaşık olarak belirlenmiştir. $\mathrm{Bu}$ sebeple ilçeler için toplamda 350 kişiye anket dağıtılması uygun görülmüştür. Geri dönen 1050 ankettense sağlıklı bir ölçüme imkân verecek olan 1000 tanesinin araştırmada kullanılmasına karar verilmiştir. Anketler dağıtılırken de örneklemin evreni temsil yeteneğini artırabilmesi adına ilçelerin nüfus oranları göz önünde bulundurulmuş ve anketler bu şekilde dağıtılmıştır. Araştırmanın veri toplama aşaması 13-29 Nisan 2015 tarihleri arasında, 18 yaş ve üstü temsil eden 1000 kişilik bir örneklem kullanılarak gerçekleştirilmiştir.

Ankette bireylere toplam 43 adet soru yöneltilmiştir. Örnek kütledeki bireylerle yüz yüze görüşülmüştür. Anket Dünya Bankası tarafından 2002 yılında Arnavutluk ve Nijerya'da uygulanan "Measuring Social Capital: An Integrated Questionnaire" ile çeşitli araştırmacıların yapmış oldukları çalışmaların incelenmesi ve toplumumuzun temel özellikleri dikkate alınarak uyarlanması sonucunda hazırlanmıştır². 
Tablo 2: Uygulamalı Analize İlişkin Sosyal Sermaye Endeksi Bileşenleri

\begin{tabular}{|c|c|}
\hline Güven Endeksi & $\begin{array}{l}\text { - } \quad \text { Genel olarak güven düzeyi } \\
\text { - } \quad \text { En çüluk güişkilerde güven duyulan kişiler } \\
\text { - } \quad \text { En çok güven duyulan kurumlar }\end{array}$ \\
\hline Network Endeksi & $\begin{array}{l}\text { - Gönüllü olarak üye olunan kuruluşlar/gruplar } \\
\text { - Üye olunan kuruluş/grupların karar alma süreçlerinde etkili } \\
\text { olma oranı } \\
\text { - Siyasi etkinliklere katılım oranı }\end{array}$ \\
\hline $\begin{array}{l}\text { Karşılıklı Yardımlaşma ve Ortak } \\
\text { İşbirliği Endeksi }\end{array}$ & $\begin{array}{l}\text { - Komşularla olan ilişkiler } \\
\text { - Toplumsal fayda sağlayan etkinliklere katııım oranı } \\
\text { - Toplumsal aktivitelerde gönüllü katılım oranı } \\
\text { - Toplumsal aktivitelere katılım amacı }\end{array}$ \\
\hline
\end{tabular}

Kaynak: Yazarlar tarafından oluşturulmuştur.

Ankette 5'li Likert Ölçeği kullanılmıştır. Sorularda en olumsuz cevabın değeri 1 puan, en olumlu cevabın değeri 5 puan olarak hesaplanmıştır. Sosyal sermaye düzeyinin tespit edilmesi amacıyla hazırlanan sorulardan, sosyal sermaye göstergeleri olarak değerlendirilen üç ayrı endeks oluşturulmuştur. Bunlar; güven endeksi, network (resmi ve gayri resmi sosyal ağlara katılım) endeksi ve karşılıklı yardımlaşma ve ortak işbirliği endeksleridir. Ankete katılan üyelerin her bir endeks için vermiş olduğu cevapların sonucu; yüksek seviyede, orta seviyede ve düşük seviyede değerlendirilmiştir. Güven endeksinde genel olarak yedi toplamda ise yirmi altı adet soru bulunmaktadır. Güven ile ilgili on beşinci soru bireylerin en çok güvendikleri kişilerin güven düzeylerini belirten yedi adet soruya, on altıncı soru ise bireylerin kurumlara duydukları güven düzeyini ölçen on dört soruya ayrılmaktadır. Güven endeksi ile ilgili altı sorudan alınabilecek en az puan 26, en fazla alınabilecek puan ise 129 'dur. $26-61$ arası alınan puanlar düşük düzey, 62-96 arası alınan puanlar orta düzey ve 97-129 arası alınan puanlar yüksek düzey olarak değerlendirilmiştir. Network endeksinde bireylerin resmi ve resmi olmayan kurumlara üyeliklerinin ve genel olarak siyasal katılım düzeylerinin ölçüldüğü üç adet soru bulunmaktadır. Gönüllü olarak üyesi olunan kuruluş ya da grupların düzeyini belirleyen yedinci soru yirmi iki seçeneğe, siyasal katılım düzeyini belirleyen kırk üçüncü soru on üç seçeneğe ayrılmaktadır. Network endeksi ile ilgili otuz altı sorudan alınabilecek en az puan 1, en fazla alınabilecek puan ise 40'tır. 1-12 arası alınan puanlar düşük düzey, 13-28 arası alınan puanlar orta düzey ve 29-40 arası alınan puanlar yüksek düzey olarak değerlendirilmiştir. Karşılıklı yardımlaşma ve ortak işbirliği endeksinde sekiz adet soru bulunmaktadır. Karşılıklı yardımlaşma ve ortak işbirliği endeksi ile ilgili sekiz sorudan alınabilecek en az puan 8, en fazla alınabilecek puan ise 36'dır. 8-15 arası alınan puanlar düşük düzey, 16-25 arası alınan puanlar orta düzey ve 26-36 arası alınan puanlar yüksek düzey olarak değerlendirilmiştir. ${ }^{3}$

Anketlerin değerlendirilmesinde SPSS Paket Programı kullanılmıştır. Bununla beraber sosyal sermaye seviyesini kent/kırsal yerleşim yerlerinin ne şekilde etkilediği ve aralarında ilişki olup olmadığını test etmek amaciyla ANOVA ve TUKEY testleri uygulanmıştır. Bağımsız değişkende çok sayıda grup varsa ANOVA testi kullanılmaktadır. Ayrıca ANOVA bağımsız değişkenlerin kendi aralarında nasıl etkileşime girdiklerini ve bu etkileşimlerin bağımlı değişken üzerindeki etkilerini analiz etmek için kullanılmaktadır (Tonta, 2008: 3). Gruplar arası farkın olduğu durumda, farklılığın hangi gruptan kaynaklı olduğunu tespit eden istatistik post-hoc olarak bilinmektedir. Varyans analizi soncunda sıfır hipotezi reddedilmesi durumu, evren ortalamalarından en az birinin diğerlerinden farklı olduğu, yani ortalamaların aynı evrende (anakütleden) gelmediği şeklinde ifade edilmektedir. Bu ortalamaların hangilerinin birbirinden farklı olduğu çoklu karşılaştırma teknikleri

${ }^{3}$ Puanlama sistemi ile ilgili olarak yazında herhangi bir kriter bulunmamaktadır. Bu bakımdan Keskin (2008)'deki hesaplama örnek alınarak puanlama yapılmıştır. 
ile belirlenmektedir. Çoklu karşılaştırma testlerinin en bilinen türlerinden bir tanesi de Tukey HSD testidir. Bu testlerin tercih edilmesinin nedeni ise araştırmanın birden fazla yığından oluşmasıdır (Greene, 2003: 33, $38,628,867)$.

$$
\begin{aligned}
& \text { Buna göre; } \\
& \mu=\text { Ortalama Sosyal Sermaye Düzeyi } \\
& \mu_{0}=\text { Aksaray Merkezin Ortalama Sosyal Sermaye }
\end{aligned}
$$
Düzeyi Düzeyi

$\mu_{1}=$ Gülağaç ilçesinin Ortalama Sosyal Sermaye

$\mu_{2}=$ Güzelyurt ilçesinin Ortalama Sosyal Sermaye Düzeyi

$$
\begin{gathered}
\mu_{3}=\text { Ortaköy ilçesinin Ortalama Sosyal Sermaye } \\
\text { Düzeyi }
\end{gathered}
$$$$
\mu_{4}=\text { Eskil ilçesinin Ortalama Sosyal Sermaye }
$$$$
\text { Düzeyi olmak üzere hipotezimiz; }
$$$$
H_{0}: \mu_{0}=\mu_{1}=\mu_{2}=\mu_{3}=\mu_{4}
$$$$
\mathrm{H}_{1} \text { : En az biri diğerlerinden farklı, şeklinde }
$$
oluşturulmuştur.

\subsection{Alan Araştırması Verilerinin Analizi ve Değerlendirilmesi}

Anket sonucunda elde edilen bulguların genel bir değerlendirilmesi yapıldığında ortaya çıkan sonuçlar sosyal sermaye kuramı açısından yararlı verilerin elde edildiği bir çalışma yapıldığını göstermektedir. Genel olarak anket sonuçları sosyal sermaye göstergelerinden olan güven, network (resmi ve gayri resmi sosyal ağlara katıım), karşılıklı yardımlaşma ve ortak işbirliği olmak üzere üç endeks oluşturularak değerlendirilmiştir. Endekslerin güvenilirliğini ölçmek amacıyla, Cronbach Alfa testi uygulanmıştır (Kayış, 2005: 405). Güven endeksinin güvenilirlik değeri $\% 80$, network endeksinin güvenilirlik değeri $\% 69$, karşılıklı yardımlaşma ve ortak işbirliği endeksinin güvenilirlik değeri \% 70 olarak bulunmuştur. Sosyal sermaye düzeyini ölçen soruların toplam güvenilirlik değeri $\% 79$ 'dur.Güvenilirlik düzeyinin yüksek olmamasının sebebi; anket uygulanan kesimin genellikle eğitim seviyesi düşük ve kırsal kesim olması nedeniyle anketin anlaşılmasını kolaylaştırmak için bazı soruların kendi içinde de farklı sorulara ayrılmasıdır.

Örnek kütlenin \% 55,4'ü erkeklerden oluşurken, \% 44,6 'sı bayanlardan oluşmaktadır. Ankete katılanların
$\%$ 24,2'si 18-25 yaş grubunda, \% 20,6'sı 25-30 yaş grubunda, \% 26,5'i 30-40 yaş grubunda, \% 16,7'si 40-50 yaş grubunda, \% 12'si ise 50 ve üstü yaş grubundadır. Ankete katılan bireylerin $\% 21$, $5^{\prime} \mathrm{i}$ ilkokul, $\%$ 4,9'u ortaokul, \%22,2'si lise, \% 49,5'i üniversite ve $\% 1,9^{\prime}$ u yüksek lisans/doktora eğitim düzeyindedir. Ankete katılan bireylerin \%29,2'si memur, \%11,7'si işçi, \%10'u emekli, \%12,6'sı serbest meslek, \%20,1'i öğrenci, \%3,1'i ise diğer meslek grubunda yer alırken $\% 13,3$ 'ü çalışmamaktadır. Ankete katılan çalışan bireylerin aylık gelir durumuna baktığımızda; \% 4,3'ü 0-500 TL, \% 23,6'sı 500-1000 TL, \% 19,9'u 1000-1800 TL, \% 29,6'sı 1800-2500 TL, \% 9,6'sı 2500 TL ve üstü gelire sahiptir. Düşük düzeyde gelire sahip olanlar genelde öğrenciler iken yüksek miktarda geliri olanlar memurlar ve serbest meslek çalışanlarıdır. Ankete katılan bireylerin \% 30'u köyde, \% 5,8'si kasabada, $\%$ 20,5'i ilçede, \% 37,2'si ilde ve $\% 6,5^{\prime}$ i büyükşehirde doğmuştur.

Ankete katılan bireylerin gönüllü olarak üyesi oldukları kurum ve kuruluşlara katılım oranları sırasıyla: Sendikalar \% 21,6; Sivil Toplum Kuruluşları \% 11,4; Okul Komitesi \% 8,4; Politik Topluluklar / Partiler $\%$ 6,7; Ticaret / Sanayi Odası \% 4,8; Çiftçi Toplulukları \% 3,8; Mesleki Topluluklar \% 2,9; Dini Topluluklar \% 2,1; Kültürel Topluluklar (Resim, Müzik, Tiyatro vb.) \% 2,1; Kadın Toplulukları \% 1,6; Çevreyi ve Hayvan Haklarını Korumayı Hedefleyen Örgütler \% 1,6; Spor Kulüpleri, Kooperatifler \% 1,2; Aile Toplulukları \% 0,9; İzcilerYavru Kurtlar Gibi Gençlik Örgütleri \% 0,5; Komşuluk / Hemşeri Toplulukları \% 0,4; İnsan Hakları ile İlgilenen Örgütler \% 0,3; Yaşlılar-Engelliler-Yoksullar İçin Görev Yapan Kuruluşlar \% 0,3; Ticari Kurumlar \% 0,2; Geri Dönüşüm Toplulukları \% 0,1'dir.

Anketin ikinci bölümünde bireylerin genel güven düzeyi, en çok güvendikleri kişiler, resmi kurumlara ne derece güvendikleri ve dayanışma düzeyleri ölçülmüştür. Güven düzeyini belirleyen sorulardan biri olan "Genel olarak insanların çoğunun güvenilir olduğunu mu düşünürsünüz, yoksa ilişkilerinizde çok dikkatli olmayı mı tercih edersiniz?" sorusuna ankete katılan bireylerin \%68,8'i insanların güvenilir olmadığı, $\%$ 23,9'u güvenilir olduğu şeklinde cevap vermiştir. \% $7,3^{\prime}$ lük bir oran insanlara güven konusunda kararsız olduğunu belirtmiştir. 
Tablo 3: ANOVA

\begin{tabular}{|l|c|c|c|c|c|}
\hline & $\begin{array}{c}\text { Kareler Toplamı } \\
\text { (Sum of squares) }\end{array}$ & $\begin{array}{c}\text { Serbestlik } \\
\text { Derecesi (df) }\end{array}$ & $\begin{array}{c}\text { Ortalama Kare } \\
\text { (Mean Square) }\end{array}$ & F Testi & $\begin{array}{c}\text { Anlamlılık Düzeyi } \\
\text { (Sig.) }\end{array}$ \\
\hline Gruplar Arası & 18,717 & 4 & 4,679 & 5,687 &, 000 \\
Gruplar icçi & 818,722 & 995 &, 823 & & \\
Toplam & 837,439 & 999 & & & \\
\hline
\end{tabular}

Kaynak: Yazarların hesaplamaları.

Tablo 4: Tukey HSD

\begin{tabular}{|l|c|c|c|}
\hline \multirow{2}{*}{ Yerleşim Yeri } & \multirow{2}{*}{ Örneklem Sayısı (N) } & \multicolumn{2}{|c|}{$\begin{array}{c}\text { Alfa alt değeri=0,05 } \\
\text { (Subset for alpha=0,05) }\end{array}$} \\
\cline { 3 - 4 } & & 1 & 2 \\
\hline Güzelyurt & 62 & 1,2903 & \\
Ortaköy & 121 & 1,3802 & \\
Eskil & 81 & 1,4198 & 1,6375 \\
Merkez & 662 & 1,6375 & 1,8243 \\
Gülağaç & 74 & & \\
\hline
\end{tabular}

Kaynak: Yazarların hesaplamaları.

Yerleşim yeri ve güven düzeyi arasında istatistikî olarak anlamlı bir ilişki bulunmuştur $(p=0,000)$. En yüksek güven düzeyi \% 36,5 ile Gülağaç ilçesine aittir. Merkezde yaşayan bireylerin insanlara güven düzeyi \% 26 'dır. Diğer ilçeleri değerlendirdiğimizde; Güzelyurt ilçesinde güven düzeyi \% 13,1 oranında, Ortaköy'de \% 14,9 ve Eskil' de \% 17,2'dir. Gülağaç ilçesinde güven düzeyinin diğerlerine göre daha yüksek olmasının sebebi orada yaşayanların çoğunlukla akraba ve hısımlık ilişkisi içerisinde olmasıdır. Aile bağlarının güçlü olduğu yerlerde bu güce paralel olarak güven düzeyi de daha fazladır.

Kurumlara duyulan güven düzeyi değerlendirildiğinde \% 80,6 güven oranı ile Silahlı Kuvvetler ilk sırada, \% 70 ile Diyanet İşleri Başkanlığı ikinci sırada yer almaktadır. Yerleşim yeri ve en çok güven duyulan kurumlar oranı arasında istatistikî olarak anlamlı bir ilişki bulunmuştur $(p=0,000)$. Sadece Diyanet İşleri Başkanlığı́na duyulan güven düzeyi yerleşim yerlerine göre farklııı göstermemektedir $(p=0,638)$. Ortaköy'de hükümete duyulan güven oranı fazla iken merkez ve Gülağaç'ta bu oran azalmaktadır. Cemaat veya tarikatlara duyulan güven düzeyi oranı en fazla Gülağaçilçesinde en az Güzelyurt ilçesindedir. Diyanet İşleri Başkanlığı́na ve eğitime güven oranı yerleşim yerlerinde yaklaşık olarak aynıdır. Türk Silahlı Kuvvetleri'nin güvenilir olduğunu düşünenlerin oranı en fazla Ortaköyilçesindedir. SivilToplum Örgütleri'nin güvenilir olduğunu belirten bireylerin oranı en fazla merkezde en az Gülağaç ilçesindedir. Adalet ve Sosyal Güvenlik Kurumları'na duyulan güven düzeyi oranı Eskil ilçesinde fazla iken Gülağaç ilçesinde daha azdır. Sağlık Kurumları'nın güvenilir olduğunu düşünen bireylerin oranı Eskil ilçesinde diğerlerine göre daha fazladır. Meslek Odaları'na duyulan güven merkezde fazla iken Gülağaç ilçesinde oldukça düşük orandadır. Millet Meclisi ve Türk polisine duyulan güven düzeyi Güzelyurt ve Eskil ilçelerinde diğerlerine oranla daha fazladır. Basın Yayın Kurumları ve Avrupa Birliği'nin güvenilir olduğunu belirtenlerin oranı Ortaköy ilçesinde oldukça yüksektir.

Üçüncü bölümde bireylerin ortak hareket etme ve birlikte iş yapabilme yeteneklerini ölçmek amacıyla sorular sorulmuştur. Son bir yılda, içinde toplumsal fayda olan herhangi bir aktiviteye (telefon ve internet yardımları hariç) katılıp diğer insanlarla birlikte çalışan bireylerin oranı sadece \% 22,6'dır. Yerleşim yeri ve toplumsal faydası olan herhangi bir aktiviteye katılıp diğer insanlarla birlikte çalışan bireylerin oranı arasında istatistikî olarak anlamlı bir ilişki bulunmuştur $(p=0,000)$. Bu oran kırsal kesime göre Aksaray merkezde daha yüksektir. "Toplumunuzdaki/ çevrenizdeki insanlar toplumsal aktivitelere gönüllü bir biçimde katılır veya yardımını esirgemez." ifadesine katılıyorum cevabını veren bireylerin oranı \% 54,9 iken katılmayanların oranı $\% 17,1$ 'dir. Yerleşim yeri ve bu ifadeye katıldığını belirten bireylerin oranı arasında istatistikî olarak anlamlı bir ilişki olduğu bulunmuştur 
$(p=0,000)$. Yerleşim yerine göre bu oranlar farklılık göstermektedir. Bu farklı grupları Tukey HSD testi göstermektedir. Örneğin; birinci grubu oluşturan Gülağaç ve Güzelyurt ilçelerinde bu ifadeye verilen cevapların oranı birbirine daha yakın ve düşük seviyededir. İkinci grupta Güzelyurt, Merkez ve Eskil yer almaktadır. Yani bu yerleşim yerlerinde oranlar birbirine daha yakın ve orta düzeydedir. Üçüncü grup olan Ortaköy ilçesi ise diğerlerinden oldukça farklı ve yüksek düzeyde bir orana sahiptir.

Tablo 5: Tukey HSD

\begin{tabular}{|l|c|c|c|c|}
\hline \multirow{2}{*}{ Yerleşim Yeri } & \multirow{2}{*}{ Örneklem Sayısı } & \multicolumn{3}{|c|}{$\begin{array}{c}\text { Alfa alt değeri=0,05 } \\
\text { (Subset for alpha=0,05) }\end{array}$} \\
\cline { 3 - 5 } & & 1 & 2 & 3 \\
\hline Gülağaç & 74 & 2,9054 & 3,1774 & \\
Güzelyurt & 62 & 3,1774 & 3,4290 & \\
Merkez & 662 & & 3,4938 & 4,1938 \\
Eskil & 81 & & & \\
Ortaköy & 121 & & \multicolumn{3}{|c|}{} \\
\hline
\end{tabular}

Kaynak: Yazarların hesaplamaları.

Uluslararası yazında yaşadığımız dönem bilgi ve iletişim çağı olarak nitelendirilmektedir. Sosyal sermayenin önemli göstergelerinden biri de bilgi paylaşımı ve iletişimdir. Bu sebeple dördüncü bölümde genel olarak bireylerin bilgi ve iletişime ne kadar önem verdikleri, bilgi ve iletişim kaynağı olarak hangi imkânları kullandıkları ölçülmüştür. Yerleşim yeri ve bilgi-iletişim düzeyi arasında anlamlı bir ilişki bulunmuştur $(p=0,000)$.

Hükümetin neler yaptığı hakkında(tarımsal büyüme, çalışma refahı, aile planlaması, vb) ya da dünyadaki gelişmeleri takip ettikleri en önemli bilgi kaynaklarını sorguladığımızda, bireylerin temel bilgi kaynağı \% 60,5 ile televizyondur. Daha sonra \% 57,3 ile internetten bilgi edindiklerine ulaşıımıştır. Akraba, arkadaş ya da komşulardan haber alanların oranı ise \% 49,9'dur. Gülağaç ilçesinde bireylerin en temel bilgi kaynağı akraba, arkadaş ya da komşularıdır. Sivil Toplum Kuruluşları'nı ve ulusal gazeteleri haber kaynağı olarak tercih edenlerin oranı en fazla merkezdedir. İnternet ağının daha fazla geliştiği Aksaray merkez, Gülağaç ve Güzelyurt'ta yaşayan bireylerin Türkiye ve dünyadaki gelişmeleri takip ettikleri en temel haber kaynağı internettir. Televizyon izleme oranları düşük olmasına rağmen merkez ve Gülağaç ilçesindeki bireyler gündemi televizyondan takip etmektedir.

Beşinci bölümde bireylerin çevreleri ile uyumu, sosyal anlamda hayatın içinde olma düzeyleri ve yaşadıklarıyerin kültürel yapısını, adet ve geleneklerini kendileri ile ne derece bütünleştirdikleri tespit edilmiştir. Yerleşim yeri ve sosyal uyum düzeyi ile ilgili sorular arasında istatistikî olarak anlamlı bir ilişki olduğu bulunmuştur ( $p=0,000)$. Yaşadığı yeri seven ve kendini oraya ait hisseden bireyler toplumsal anlamda diğerlerine oranla daha fazla verimlidir. Ankete katılan bireylerin \% 55'i kendini bu şehre ait hissederken, $\% 19,5^{\prime} \mathrm{i}$ bu şehirde yaşamayı tercih etmemektedir. Ortaköy ve Eskil ilçelerinde ikamet edenler bireylerin kendilerini Aksaray'a ve yaşadıkları yere ait hissetme oranları oldukça yüksektir. Buna rağmen Gülağaç ilçesindeki bireyler daha düşük düzeyde kendilerini bu şehrin bir parçası olarak görmektedir. Ankete katılan bireylerin yaşam alanlarını güzelleştirmek ya da iyileştirmek anlamında toplumsal etkinliklerde rol almayı önemseyenlerin oranı \% 22 iken yaşanılan şehrin sosyal, ekonomik, kültürel, yaşam boyutları anlamında bir parçası olmanın önemli olmadığını düşünenlerin oranı \% 50'dir. Merkez ve Gülağaç ilçesindeki bireyler yaşadıkları yerin toplumsal anlamda bir parçası olmanın çok önemli olduğunu belirtmiştir.

Anketin son bölümünde siyasi bilinç ve siyasi etkinler ile Aksaray Belediyesi'nin sunduğu hizmetlerin değerlendirilmesi yapılmıştır. "Aksaray Belediyesi'nin çalışmalarından memnunum." ifadesine katılan bireylerin oranı \% 22,4 iken belediyenin çalışmalarından memnun olmayan bireylerin oranı $\% 64,8^{\prime}$ dir. Yerleşim yeri ve Aksaray Belediyesi ile ilgili sorulara verilen cevapların oranı arasında istatistikî olarak anlamlı bir ilişki bulunmuştur $(p=0,000)$. Ankete katılan bireylerin son 3 yıl içerisinde yaptıkları siyasi etkinliklere baktığımızda; Aksaray'da siyasal katıımın düşük olduğu ve \% 90 ile oy vermek haricindeki en yaygın siyasal katılımın \% 24,6 ile kişisel sorunlarla 
ilgili dilekçe yazmak olduğu görülmektedir. İnternet eylemine katılan bireylerin oranı \% 24,1'dir. Siyasi etkinliklere katılım düzeyi ile yerleşim yeri arasındaki ilişkinin istatistikî olarak anlamlı olduğu bulunmuştur $(p=0,000)$. Merkezde yaşayan bireylerin ilçelere oranla internet eylemine daha fazla katıldığı tespit edilmiştir.
Ortaköy ve Eskil ilçesindeki bireylerin mahalledeki sorunlarla ilgili dilekçe yazma oranı oldukça düşüktür. Siyasi parti gençlik kollarına üye olan ve toplu yürüyüşe katılan bireylerin oranı Ortaköy ilçesinde daha fazladır.

Tablo 6: Yerleşim Yerine Göre Sosyal Sermaye Düzeyi (\%)

\begin{tabular}{|c|c|c|c|c|}
\hline Yerleşim Yeri & Sosyal Sermaye Endeksleri & Düzey & Sıklık Sayısı & Oran (\%) \\
\hline \multirow{9}{*}{ Merkez } & \multirow{3}{*}{ Güven } & Düşük & 47 & 7,1 \\
\hline & & Orta & 603 & 91,1 \\
\hline & & Yüksek & 12 & 1,8 \\
\hline & \multirow{3}{*}{ Network } & Düşük & 656 & 99,1 \\
\hline & & Orta & 6 & 0,9 \\
\hline & & Yüksek & 0 & 0 \\
\hline & \multirow{3}{*}{ Karşılıklı yardımlaşma ve ortak işbirliği } & Düşük & 22 & 3,3 \\
\hline & & Orta & 420 & 63,5 \\
\hline & & Yüksek & 220 & 33,2 \\
\hline \multirow{9}{*}{ Gülağaç } & \multirow{3}{*}{ Güven } & Düşük & 25 & 33,8 \\
\hline & & Orta & 48 & 64,8 \\
\hline & & Yüksek & 1 & 1,4 \\
\hline & \multirow{3}{*}{ Network } & Düşük & 73 & 98,6 \\
\hline & & Orta & 1 & 1,4 \\
\hline & & Yüksek & 0 & 0 \\
\hline & \multirow{3}{*}{ Karşılıklı yardımlaşma ve ortak işbirliği } & Düşük & 1 & 1,3 \\
\hline & & Orta & 47 & 63,5 \\
\hline & & Yüksek & 26 & 35,2 \\
\hline \multirow{9}{*}{ Güzelyurt } & \multirow{3}{*}{ Güven } & Düşük & 3 & 4,8 \\
\hline & & Orta & 59 & 95,2 \\
\hline & & Yüksek & 0 & 0 \\
\hline & \multirow{3}{*}{ Network } & Düşük & 61 & 98,4 \\
\hline & & Orta & 1 & 1,6 \\
\hline & & Yüksek & 0 & 0 \\
\hline & \multirow{3}{*}{ Karşııklı yardımlaşma ve ortak işbirliği } & Düşük & 1 & 1,6 \\
\hline & & Orta & 34 & 54,8 \\
\hline & & Yüksek & 27 & 43,6 \\
\hline \multirow{9}{*}{ Ortaköy } & \multirow{3}{*}{ Güven } & Düşük & 0 & 0 \\
\hline & & Orta & 119 & 98,4 \\
\hline & & Yüksek & 2 & 1,6 \\
\hline & \multirow{3}{*}{ Network } & Düşük & 119 & 98,4 \\
\hline & & Orta & 2 & 1,6 \\
\hline & & Yüksek & 0 & 0 \\
\hline & \multirow{3}{*}{ Karşılıklı yardımlaşma ve ortak işbirliği } & Düşük & 0 & 0 \\
\hline & & Orta & 45 & 37,2 \\
\hline & & Yüksek & 76 & 62,8 \\
\hline \multirow{9}{*}{ Eskil } & \multirow{3}{*}{ Güven } & Düşük & 3 & 3,7 \\
\hline & & Orta & 76 & 93,9 \\
\hline & & Yüksek & 2 & 2,4 \\
\hline & \multirow{3}{*}{ Network } & Düşük & 81 & 100,0 \\
\hline & & Orta & 0 & 0 \\
\hline & & Yüksek & 0 & 0 \\
\hline & \multirow{3}{*}{ Karşılıklı yardımlaşma ve ortak işbirliği } & Düşük & 0 & 0 \\
\hline & & Orta & 56 & 69,1 \\
\hline & & Yüksek & 25 & 30,9 \\
\hline
\end{tabular}

Kaynak: Yazarların hesaplamaları. 
Aksaray ili ve ilçelerine ilişkin sosyo-ekonomik gelişmişlik farklarını gösteren araştırmaya göre sosyo-ekonomik olarak ilçelerin gelişmişlik sıralaması en gelişmişten en az gelişmişe göre şöyledir: Aksaray Merkez, Ortaköy, Eskil, Güzelyurt ve Gülağaç (Ahiler Kalkınma Ajansı, 2013: 22-23).

Tablo 7: Sosyo-Ekonomik Gelişmişlik Endeksi

\begin{tabular}{|c|c|c|}
\hline $\begin{array}{c}\text { Gelişmişlik } \\
\text { Sıralaması }\end{array}$ & İlçe & $\begin{array}{c}\text { Gelişmişlik } \\
\text { Endeksi }\end{array}$ \\
\hline 1 & Aksaray Merkez & 2,09756 \\
\hline 2 & Ortaköy & 0,20321 \\
\hline 3 & Eskil & $-0,3558$ \\
\hline 4 & Güzelyurt & $-0,82941$ \\
\hline 5 & Gülağaç & $-1,03007$ \\
\hline
\end{tabular}

Kaynak: Ahiler Kalkınma Ajansı 2013: 22-23.

Çalışmamızda yaptığımız sosyal sermaye analiz sonuçları ile sosyo-ekonomik gelişmişlik çalışması sonuçları karşılaştırıldığında aşağıdaki bulgulara ulaşmak mümkündür:

- Aksaray Merkez hem sosyal sermaye stoku hem de sosyo-ekonomik gelişmişlik seviyesi bakımından en yüksek değerlere sahiptir. Sosyal sermayenin önemli göstergelerinden olan güven ve network endeksi Aksaray merkezde diğer ilçelere göre daha yüksek düzeydedir. Karşılıklı yardımlaşma ve ortak işbirliği endeksinin ise merkezde orta düzeyde olduğu görülmektedir. $\mathrm{Bu}$ bağlamda sosyal sermaye stoğunun fazla olduğu merkezde sosyo-ekonomik gelişsmişlik seviyesinin ve kalkınmanın da yüksek olduğunu söyleyebiliriz.

- Sosyo-ekonomik gelişmişlik çalışmasına göre ikinci sırada yer alan Ortaköy ilçesi sosyal sermaye stoku açısından güven endeksinin orta düzeyde, network endeksinin ise düşük seviyede olduğu görülmektedir. Sosyal sermayenin önemli göstergelerinden olan karşılıklı yardımlaşma ve ortak işbirliği endeksi ise merkez ve diğer ilçelere oranla yüksek düzeydedir. Ortaköy ilçesinde sosyal ağlara katılım düzeyinin düşük olması sosyal sermaye stokunu olumsuz etkilemektedir. İlçedeki sivil örgütlenmenin ve ağ bağlantılarının artırılması durumunda sosyal sermaye düzeyi de artacaktır. Bunun sonucunda da sosyoekonomik gelişmişlik düzeyi zaten yüksek olan ilçenin kalkınma düzeyi de artacaktır.
- Aksaray merkeze en uzak olan ve sosyoekonomik gelişmişlik çalışması sonucuna göre üçüncü sırada yer alan Eskil ilçesinde beşeri sermaye kalitesi daha yüksek iken bölgenin sosyal sermaye stoğu oldukça düşük düzeydedir. Sosyal sermaye endeksleri açısından ilçede; güven ve karşılıklı yardımlaşma endeksi orta düzeyde iken network endeksi oldukça düşük seviyededir. İlçenin Aksaray merkeze uzak olması, ilçede yaşayan bireylerin merkez ile olan ağ bağlantılarında kopukluğa neden olmakta ve daha muhafazakâr bir toplum oluşmasına neden olmaktadır. Bu da ilçedeki sosyal gelişmişliği olumsuz etkilemektedir. Eskil ilçesinde beşeri sermaye ile birlikte sosyal sermaye stokunun eşanlı artırılması sonucunda bölgenin kalkınma düzeyi de artacaktır.

- Aksaray merkeze yakın olan Gülağaç ve Güzelyurt ilçeleri sosyal sermaye stoku açısından diğer ilçelere oranla daha yüksek seviyededir. Gülağaç ilçesinde güven endeksi yüksek düzeyde, network endeksi orta düzeyde ve karşılıklı yardımlaşma endeksi ise düşük düzeydedir. Güzelyurt ilçesinde ise güven endeksi düşük seviyede, network endeksi ve karşılıklı yardımlaşma endeksi orta seviyededir. Sosyoekonomik gelişmişlik çalışmasına göre Güzelyurt ve Gülağaç ilçeleri düşük oranlara sahiptir. Sosyal sermaye stoku açısından avantajlı konumda olan ilçelerin eğitim, sağlık gibi yaşam standartlarının daha da iyileştirilmesi durumunda bölgesel kalkınma potansiyellerinin artacağını ve bölgesel kalkınma oranları açısından Aksaray merkeze rakip olabileceklerini söylemek mümkündür.

\section{SONUÇ ve ÖNERILER}

Sosyal sermaye konusunda yapılan çalışmalar ve sosyal sermaye düzeyini ölçmeye yönelik uygulamalı araştırmaların birçoğu sosyal sermayenin toplumsal düzen ve ekonomik kalkınma üzerinde pozitif katkısının olduğunu göstermektedir. Ülkeler açısından baktığımızda; sosyal sermayesi yüksek olan toplumların daha kolay kalkındığı, kamu bürokrasisinin daha iyi çalıştığı, demokrasinin daha fazla yerleştiği ve insanların yaşam standartlarının daha iyi olduğu görülmektedir.

Bölgesel kalkınma açısından sosyal sermaye stoku ve sosyo-ekonomik gelişmişlik arasında pozitif bir ilişki vardır. Sosyal sermayenin önemli göstergelerinden olan güven, network ve karşılıklı 
yardımlaşma düzeyi ile birlikte sağlık, eğitim gibi yaşam standartlarının da iyileştirilmesi bölgenin kalkınma düzeyini artırmaktadır. Aile içi dayanışmanın çok güçlü, buna karşılık sivil örgütlenmenin ve ağ bağlantılarının zayıf olduğu Aksaray merkez ve ilçelerinde yeniliklerin kabul edilmesi, benimsenmesi ve toplum içinde yayılması zor olmaktadır. Bu durum yeniliğe dayalı bölgesel kalkınma stratejilerinin işleyebilmesini engellemektedir. Sosyal sermaye ve yenilikler arasındaki pozitif ilişkinin sonucu olarak sosyal sermaye bakımından zengin olan bölgenin diğerlerine oranla daha hızlı ve daha yüksek ölçekte bir teknolojik ilerleme yaşaması imkânına sahip olması anlamına gelmektedir. Aksaray Merkez hem sosyal sermaye stoku hem de sosyo-ekonomik gelişmişlik seviyesi bakımından en yüksek değerlere sahiptir. Sosyo-ekonomik gelişmişlik açısından ikinci sırada yer alan Ortaköy ilçesinde sosyal sermaye düzeyinin de yüksek olduğu görülmektedir. Aksaray merkeze en uzak olan ve sosyo-ekonomik gelişmişlik çalışması sonucuna göre üçüncü sırada yer alan Eskil ilçesinde beşeri sermaye kalitesi daha yüksek iken bölgenin sosyal sermaye stoku oldukça düşük düzeydedir. Beşeri sermaye ile birlikte sosyal sermaye stokunun eşanlı artırılması sonucunda bölgenin kalkınma düzeyi de artacaktır. Sosyal sermaye stoku açısından daha iyi konumda olan Gülağaç ve Güzelyurt ilçelerinin eğitim, sağlık gibi yaşam standartlarının daha da iyileştirilmesi durumunda Aksaray merkeze rakip bir bölgesel kalkınma potansiyeli sergileyeceklerini söylemek mümkündür.

Genel olarak değerlendirildiğinde, sosyal sermaye ve bölgesel kalkınma arasında pozitif bir ilişki olduğu görülmektedir. Sosyal sermaye bölgesel kalkınmayı; bilginin daha kolay yayılması, zor zamanlarda karşııklı yardımlaşma ve gayri resmi sigorta işlevi görme, toplumda suç oranlarının azalması, işsizliğin ve yolsuzluğun azalması, resmi ve gayri resmi ağlara üyeliklerin artması, politik katılım, ortak işbirliği gibi sonuçlarla etkilemektedir. Dolayısıyla bölgesel kalkınmanın sağlanması için, bölgesel bir stratejiyi içselleştirmek ve yerel kimliği canlandırmak; işbirliği, katılım ve karşılıklı ilişkileri güçlendirme kapasitesini kurmak ve insan sermayesini güçlendirmeyi, bilgiye ve yenilikçiliğe yatırım yapmayı öncelikli hale getiren bir kültürü kabullenmek anlamındaki sosyal sermayenin kurulması gerekmektedir.

\section{KAYNAKLAR}

AHILER KALKINMA AJANSI (2013) "TR71 Bölgesi İlçeleri Sosyo-Ekonomik Gelişmişlik Analizi" ss. 8-106.

ARI HAREKETI (2005) "Türk toplumu ve Sosyal Sermaye", [http://www.ari.org.tr/index_tr.asp], Erişim: (04/03/2015).

CALLOIS, J. M. ve AUBERT F. "Towards indicators of social capital for regional development issues". 2005.

COLEMAN, J. S. (1988) "Social Capital in The Creation of Human Capital", American Journal of Sociology, Vol. 94, No: 94, pp.95-120.

EŞKİ, H. (2009) "Sosyal Sermaye -Önemi, Üretimi ve Ölçümü Üzerine Bir Alan Araştırması" Doktora Tezi, Konya.

FLORIDA, R. (2005) Cities and the Creative Class, Routledge, New York, USA.

FUKUYAMA, F. (2000) "Social Capital and Civil Society", IMF Working Paper, WP/00/74.

FUKUYAMA, F. (2005) "Güven, Sosyal Erdemler ve Refahın Yaratılması” İstanbul: Türkiye İş Bankası Kültür Yayınları.

GRANOVETTER, M. S. (2005) "The Impact of Social Structure on Economic Outcomes", Journal of
Economic Perspectives, Vol. 19, No: 1, pp. 33-50.

GREEN, W. H. (2003) Econometric Analysis, $5^{\text {th }}$ Edition, Prentice Hall, New York, USA.

HANIFAN, Lyda J. (1916) “The Rural School Community Center", Annals of the American Academy of Political and Social Science, Vol. 67, pp.130-138.

IYER, S.; M. KITSON; B. TOH (2005) "Social Capital, Economic Growth and Regional Development", Regional Studies, Vol.39, No: 8, pp.1015-1040.

KAYIŞ, A. (2005), "Güvenilirlik Analizi", SPSS Uygulamalı Çok Değişkenli İstatistik Teknikleri, Ed: Şeref Kalaycı, Asil Yayınları, Ankara.

KESKiN, M. (2008), "Sosyal Sermaye ve Bölgesel Kalkınma: Erzurum Ticaret ve Sanayi Odası Üyelerinde Sosyal Sermaye Düzeyi ve Belirleyicilerinin Analizi", Yüksek Lisans Tezi, Atatürk Üniversitesi Sosyal Bilimler Enstitüsü İktisat Anabilim Dalı, Erzurum.

KNOWLES, S. (2005) "The Future of Social Capital in Development Economics Research", A Paper Prepared for theWIDER Jubilee Conference: Thinking Ahead:The Future of Development Economics, Helsinki, (Çevrimiçi)http//www.business.otago.ac.nz/ econ/Per sonal/SK/soccap_05.pdf, 
ÖZCAN, B. (2011) "Sosyal Sermaye ve Ekonomik Kalkınma" Doktora Tezi, İstanbul Üniversitesi Sosyal Bilimler Enstitüsü, İstanbul.

PORTES, A. ve LANDOLT P. (2000), "Social Capital: Promise and Pitfalls of Its Role in Development", Journal of Latin American Studies, Vol. 32, No. 2, May, pp. 529-547.

PUTNAM, R. D. (1995a) “Bowling Alone: America's Declining Social Capital",(Çevrimiçi)http//www. eaglenet.lambuth.edu /.../Bowling.pdf,.

PUTNAM, R. D. (1995b) "Tuning In, Tuning Out: The Strange Disappearance of Social Capital in America", Political Science andPolitics, Vol. 28, No: 4, pp. 664683.

PUTNAM, R. D. (2000) Bowling Alone: The Collapse and Revival of American Community, Simon \& Schuster, NewYork.

SCHAIK, V. T.(2002) "Social Capital in the European Values Study Surveys", Paper for OECD-ONS InternationalConference Social Capital Measurement in London,(Çevrimiçi) http://www.oecd.org/ innovation/research/2381883.pdf
The World Bank Social Capital/Measurement Tools. [web.worldbank.org/.../EXTSOCIALDEVE)], Erişim: (29/11/2011).

TONTA, Y. (2008) "Varyans Analizi (ANOVA) ve Faktöriyel ANOVA" (Çevrimiçi) http://yunus.hacettepe. edu.tr/ tonta/courses/fall2007/sb5002/sb5002-10varyansanalizi.pdf

TÜYSÜZ, N. (2011) "Sosyal Sermayenin Ekonomik Gelişme Açısından Önemi ve Sosyal Sermaye Endeksinin Hesaplanması" Uzmanlık Tezi, Kalkınma Bakanlığı, Ankara.

VELIBEYOĞLU, K. (2009), “Bardağın Yarısı Dolu: Yerel Kalkınmada Varlık Temelli Yaklaşım", Ege Mimarlık, 71/4, ss. 42-44.

WOODHOUSE, A. (2006) "Social capital and economic development in regional Australia: A case study". Journal of Rural Studies, 22.

WOOLCOCK, M. 2001. The place of social capital in understanding social and economic outcomes. The contribution of Human and Social Capital to Sustained Economic Growth and Well-Being. International Symposium Report. Human Resources Development Canada (HRDC) and OECD. 


\section{EK - 1 Sosyal Sermaye ve Kalkınmaya İlişkin Literatür Taraması}

\begin{tabular}{|c|c|c|}
\hline $\begin{array}{l}\text { Araştırmayı } \\
\text { Yapanlar }\end{array}$ & $\begin{array}{c}\text { Araştırmanın } \\
\text { Yapıldığı Ülke/Yıl }\end{array}$ & Araştırmanın Yöntemi ve Bulguları \\
\hline DÜNYA BANKASI & 47 Ülke (1995) & $\begin{array}{l}\text { Korelasyon Yöntemi. } \\
\text { Gelişmişlik düzeyi yüksek olan ülkelerin sosyal sermaye düzeyinin } \\
\text { de yüksek olduğu, dolayısıyla sosyo-ekonomik kalkınma } \\
\text { göstergeleri ile sosyal sermaye düzeyi arasında da güçlü bir } \\
\text { korelasyon olduğu tespit edilmiştir. }\end{array}$ \\
\hline Paul WHITELEY & 34 Ülke (2000) & $\begin{array}{l}\text { Temel Bileşenler Analizi yöntemi. } \\
\text { Ekonomik performans ve sosyal sermaye arasındaki ilişkiye } \\
\text { bakıldığında; sosyal sermayenin ekonomik büyümeyi artırdığı, } \\
\text { bununla birlikte beşeri ve fiziki yatırımı teşvik ettiği tespit } \\
\text { edilmiştir. }\end{array}$ \\
\hline Reino HJERPPE & 27 Ülke (1998) & $\begin{array}{l}\text { Güvenin büyüme üzerinde pozitif bir etkiye sahip olduğu ve } \\
\text { yüksek güven düzeyinin, ekonominin yatırım iklimini de olumlu } \\
\text { yönde etkilediği saptanmıştır. }\end{array}$ \\
\hline $\begin{array}{l}\text { Sjoerd } \\
\text { BEUGELSDIJK ve } \\
\text { Ton Van SCHAIK }\end{array}$ & $\begin{array}{c}7 \text { Avrupa Bölgesi } \\
\text { (2003) }\end{array}$ & $\begin{array}{l}\text { Regresyon yöntemi. } \\
\text { Güven ile büyüme arasında güçlü bir korelasyon bulunmazken, } \\
\text { aktif grup üyeliği ve yatay ağlar ile büyüme arasındaki } \\
\text { korelasyonun güçlü olduğu tespit edilmiştir. }\end{array}$ \\
\hline $\begin{array}{l}\text { Jan FIDRMUC ve } \\
\text { Klarita GERXHANI }\end{array}$ & $\begin{array}{l}15 \text { AB Ülkesi ve } \\
13 \text { AB Adayı Ülke } \\
\text { (2004) }\end{array}$ & $\begin{array}{l}\text { Logit Model. } \\
\text { Gençlerin ve kırsalda ikamet edenlerin sosyal ağlara daha fazla } \\
\text { katılığı tespit edilmiştir. }\end{array}$ \\
\hline $\begin{array}{c}\text { Helje KALDARU ve } \\
\text { Eve PARTS }\end{array}$ & $\begin{array}{c}34 \text { Avrupa Ülkesi } \\
\text { (2005) }\end{array}$ & $\begin{array}{l}\text { Temel Bileşenler Analizi. } \\
\text { İnsan sermayesi, sosyal sermaye, gelir eşitsizliği, kişi başı GSYiH, } \\
\text { insani kalkınma indeksi ve net tasarrufların; insani kalkınma } \\
\text { indeksindeki değişimin } 86,1 \% \text { 'ini açıkladığı ve insan sermayesi ile } \\
\text { sosyal sermayenin bu değişkenler arasından kalkınma üzerinde } \\
\text { en fazla etkiye sahip değişkenler olduğu tespit edilmiştir. }\end{array}$ \\
\hline $\begin{array}{c}\text { Asimina } \\
\text { CHRISTOFOROU }\end{array}$ & $\begin{array}{c}32 \text { Avrupa Ülkesi } \\
\text { (2006) }\end{array}$ & $\begin{array}{l}\text { Yatay Kesit Ülke Analizi. } \\
\text { Sosyal sermayenin ekonomik büyümeye oranla, insani kalkınma } \\
\text { ile daha güçlü ve pozitif bir ilişki içerisinde olduğu sonucuna } \\
\text { varılmıştır. }\end{array}$ \\
\hline $\begin{array}{l}\text { 1. Paul J. ZAK ve } \\
\text { Stephen KNACK }\end{array}$ & 37 Ülke (2001) & $\begin{array}{l}\text { Yatay Kesit Ülke Analizi. } \\
\text { Yüksek güven düzeyine sahip toplumların daha yüksek yatırım } \\
\text { ve büyüme oranlarına sahip oldukları sonucuna ulaşılmıştır. }\end{array}$ \\
\hline
\end{tabular}




\begin{tabular}{|c|c|c|}
\hline $\begin{array}{l}\text { Isabel NEIRA, Marta } \\
\text { PORTELA ve Elvira } \\
\text { VIEIRA }\end{array}$ & $\begin{array}{l}14 \text { OECD Ülkesi } \\
(2009)\end{array}$ & $\begin{array}{l}\text { Sabit etkiler panel veri modeli. } \\
\text { Çalışma, sosyal sermaye ile insan sermayesi arasında pozitif bir } \\
\text { etkileşimin varlığıyla beraber, her iki değişkenin de kalkınmayı } \\
\text { olumlu etkilediğini ortaya koymuştur. }\end{array}$ \\
\hline $\begin{array}{l}\text { Mehmet KARAGÜL } \\
\text { ve Selçuk AKÇAY }\end{array}$ & 36 Ülke (2002) & $\begin{array}{l}\text { Yatay Kesit Ülke Analizi. } \\
\text { Yüksek sosyal güven düzeyine sahip ülkelerin, aynı zamanda } \\
\text { ekonomik büyüme açısından da ileride oldukları tespit edilmiştir. }\end{array}$ \\
\hline Terrence CASEY & İngiltere (1999) & $\begin{array}{l}\text { Korelasyon yöntemi. } \\
\text { Araştırma sonucunda ekonomik performans ile güven düzeyi } \\
\text { arasında güçlü bir korelasyon bulunmuştur. Kuzeye gittikçe güven } \\
\text { düzeyinin güney bölgelere göre azaldığı tespit edilmiştir. }\end{array}$ \\
\hline Fabio SABATINI & İtalya (2005) & $\begin{array}{l}\text { Temel Bileşenler Analizi. } \\
\text { Eğitime ilgi, sağlık sistemi, refahı artıııı çalışmalar ve çevreyi } \\
\text { koruma ile hem sosyal sermaye hem de kalkınma göstergeleri } \\
\text { arasında güçlü korelasyon olduğu tespit edilmiştir. Bağlayıcı sosyal } \\
\text { sermayenin (güçlü aile bağları) kalkınma ile negatif, birleştirici } \\
\text { (gönüllü organizasyonlar) ve köprü (zayıf gayri resmi bağlar) kuran } \\
\text { sosyal sermayenin ise pozitif ilişkili olduğunu tespit etmiştir }\end{array}$ \\
\hline $\begin{array}{l}\text { Sriya IYER, Michael } \\
\text { KITSON ve Bernard } \\
\text { TOH }\end{array}$ & $A B D(2000)$ & $\begin{array}{l}\text { Logit model. } \\
\text { Araştırma sonucunda; eğitimin, istihdamın, aynı yerde uzun süre } \\
\text { ikamet etmenin sosyal sermayeyi artırdığı görülmüştür. Sosyal } \\
\text { sermayenin tüm göstergeleri için anlamlı olmamasına rağmen } \\
\text { kırsal alanlarda kentsel alanlara göre daha fazla sosyal sermaye } \\
\text { olduğu sonucuna ulaşılmıştır }\end{array}$ \\
\hline $\begin{array}{l}\text { Jean Marc CALLOIS } \\
\text { ve Francis AUBERT }\end{array}$ & Fransa (2005) & $\begin{array}{l}\text { Temel Bileşenler Analizi. } \\
\text { Bölgesel kalkınma açısından, köprü kuran sosyal sermayenin yani } \\
\text { dış bağlantıların, bağlayıcı ve birleştirici sosyal sermayeden daha } \\
\text { önemli bir unsur olduğu kanıtlanmıştır. }\end{array}$ \\
\hline $\begin{array}{l}\text { Andrew } \\
\text { WOODHOUSE }\end{array}$ & $\begin{array}{l}\text { Avustralya } \\
(2001-2002)\end{array}$ & $\begin{array}{l}\text { Temel Bileşenler Analizi. } \\
\text { Ekonomik kalkınma düzeyi yüksek olan kesimin sosyal sermaye } \\
\text { seviyesinin de yüksek olduğu görülmüştür. Ayrıca araştırmada } \\
\text { sosyal sermaye ve ekonomik kalkınma arasında pozitif bir ilişki } \\
\text { olduğu kanıtlanmıştır. }\end{array}$ \\
\hline
\end{tabular}




\begin{tabular}{|c|c|c|}
\hline $\begin{array}{l}\text { Anil RUPASINGHA, } \\
\text { Stephan J. GOETZ ve } \\
\text { David FRESHWATER }\end{array}$ & ABD (2002) & $\begin{array}{l}\text { Baro Tipi Büyüme Modeli. } \\
\text { Sosyal sermaye ve büyüme arasında pozitif bir ilişki olduğu } \\
\text { sonucunu ortaya koyarken insan sermayesi yatırımlarının, } \\
\text { kentsel alanlara yakınlık ve erişilebilirliğin de ekonomik } \\
\text { büyüme üzerinde pozitif etkilere yol açtığını saptamıştır. }\end{array}$ \\
\hline Giovanni PERI & İtalya (2004) & $\begin{array}{l}\text { Kamusal katılım gibi sosyal içerikli değişkenlerin ekonomik } \\
\text { performansı arttırdığına pek fazla kanıt sunmamakla } \\
\text { beraber, bu değişkenlerin yüksek düzeylerinin organize } \\
\text { suçları azalttığını tespit etmiştir. }\end{array}$ \\
\hline Ron A. BOSCHMA & İtalya (2005) & $\begin{array}{l}\text { Korelasyon yöntemi. } \\
\text { Sosyo-kültürel alt yapı açısından daha gelişmiş olan } \\
\text { bölgenin diğer bölgelere göre daha iyi ekonomik } \\
\text { performans sergilediği tespit edilmiştir. }\end{array}$ \\
\hline $\begin{array}{l}\text { Deepa NARAYAN ve } \\
\text { Lant PRITCHETT }\end{array}$ & Tanzanya (1995) & $\begin{array}{l}\text { Regresyon yöntemi. } \\
\text { Daha fazla sosyal sermayeye sahip hane halklarının daha } \\
\text { fazla kamu hizmetinden faydalandığı, gelişmiş tarımsal } \\
\text { yöntemleri kullandığı, toplumsal aktivitelere katılığı ve } \\
\text { tarımsal gelişme için kredi kullandıkları, bu sayede de } \\
\text { sosyal sermayenin gelir artışında rol oynadığı sonucuna } \\
\text { varmışlardır }\end{array}$ \\
\hline Mina N. BALIAMOUNE & $\begin{array}{l}39 \text { Afrika Ülkesi } \\
\text { (2005) }\end{array}$ & $\begin{array}{l}\text { Sabit etkiler panel veri modeli. } \\
\text { Sosyal sermayenin kurumsal kalite ve insan sermayesi ile } \\
\text { etkileşiminin de ekonomik kalkınma üzerinde pozitif etkiye } \\
\text { yol açtığı tespit edilmiştir. }\end{array}$ \\
\hline Anirudh KRISHNA & $\begin{array}{l}\text { Hindistan/ } \\
\text { Rajasthan (1998- } \\
\text { 2000) }\end{array}$ & $\begin{array}{l}\text { Regresyon yöntemi. } \\
\text { Sosyal sermaye ve kalkınma arasında pozitif bir ilişki } \\
\text { olduğu tespit edilmiştir. }\end{array}$ \\
\hline Christian GROOTAERT & Endonezya (1999) & $\begin{array}{l}\text { Yapısal denklem modeli. } \\
\text { İnsan sermayesinin ve sosyal sermayenin hane halkı } \\
\text { refahı üzerinde pozitif ve anlamlı etkilere sahip oldukları } \\
\text { sonucuna ulaşılmıştır. }\end{array}$ \\
\hline Arı Hareketi & 15 il (2005) & $\begin{array}{l}\text { Anket cevaplarının yüzdeleri. } \\
\text { Türk toplumunun sosyal sermaye düzeyi düşük çıkmıştır. }\end{array}$ \\
\hline TESEV & $\begin{array}{l}17 \text { il (2000) } \\
12 \text { il (2003) } \\
20 \text { il (2004) }\end{array}$ & $\begin{array}{l}\text { Anket cevaplarının yüzdeleri } \\
\text { Türkiye'de en güvenli kurumun Türk silahlı kuvvetleri } \\
\text { olduğu tespit edilmiştir. Ayrıca yapılan ankette "insanların } \\
\text { çoğuna güvenilmez" cevabı yüksek oranda çıkmıştır. }\end{array}$ \\
\hline Feray ERSELCAN & $\begin{array}{l}\text { Sivas, Kayseri, } \\
\text { Yozgat (2009) }\end{array}$ & $\begin{array}{l}\text { Korelasyon yöntemi. } \\
\text { Sosyal ilişkilerine yaptıkları yatırım sayesinde, daha yüksek } \\
\text { ortak eylem düzeyine ve daha düşük işlem maliyetlerine } \\
\text { sahip firmaların daha iyi performans gösterdikleri } \\
\text { sonucuna ulaşılmıştır. }\end{array}$ \\
\hline Alpay FILIZTEKIN & $\begin{array}{l}\text { Türkiye Geneli } \\
\text { (2009) }\end{array}$ & $\begin{array}{l}\text { Temel Bileşenler Analizi. } \\
\text { Sosyal sermaye endeksi açısından Ankara ve İstanbul ilk iki } \\
\text { sırada yer alırken, üçüncü sırada Muğla almaktadır. Endeks } \\
\text { sıralamasının sonunda ise Mardin, Ağrı ve Muş illeri yer } \\
\text { almıştır. }\end{array}$ \\
\hline
\end{tabular}




\section{EK - 2: Çalışmada Uygulanan Anket}

\section{A. Cevaplayıcıya Dair Bilgiler}

\section{1) Cinsiyetiniz: Kadın ( ) Erkek ( )}

2) Yaşınız: 18-25 ( ) 25-30 ( ) 30-40 ( ) 40-50 ( ) 50 yaş ve üzeri ( )

3) Eğitim düzeyiniz: Illkokul( ) Ortaokul( ) Lise( ) Üniversite( ) Yüksek Lisans/Doktora( )

4) Mesleğiniz: Memur ( ) İşçi ( ) Emekli ( ) Serbest Meslek ( ) Öğrenci ( ) Çalışmıyor ( ) Diğer ( )

5) Gelir Düzeyiniz (Aylık): 0-500 TL ( ) 500-1000 TL ( ) 1000-1800 TL ( ) 1800-2500 TL ( ) 2500 TL ve üzeri ( )

6) Doğduğunuz yer aşağıdakilerden hangisine uygundur?
1.Köy ( )
2.Kasaba ( )
3.illçe ( )
4. II ( )
5.Büyükşehir ( )

\section{B. Gruplar, Ağlar ve Sivil Katılım}

7) Gönüllü olarak üyesi olduğunuz kuruluşları/grupları işaretleyiniz?
1. Sendikalar ( )
12. Sivil Toplum Kuruluşları ( )
2. Çiftçi Toplulukları ( )
13. Okul Komitesi ( )
3. Ticari Kurumlar ( )
14. Sağlık Komitesi ( )
4. Kooperatifler ( )
15. Geri Dönüşüm Toplulukları ( )
5. Kadın Toplulukları ( )
16. Spor Kulüpleri ( )
6. Dini Topluluklar ( )
17. Mesleki Topluluklar ( )
7. Komşuluk / Hemşeri Toplulukları ( )
18. Ticaret / Sanayi Odası ( )
8. Aile Toplulukları ( )
19. Politik Topluluklar / Partiler ( )
9. İzciler, Yavru Kurtlar Gibi
20. İnsan Hakları ile İlgilenen Gençlik Örgütler ( )
Örgütleri ( )
10. Kültürel Topluluklar (Resim, İçin Görev Yapan Kuruluşlar ( )
21.Yaşlılar, Engelliler ve Yoksullar Müzik, Tiyatro vb.) ( )
11. Çevreyi ve Hayvan Haklarını
22.Diğer ( ) Korumayı Hedefleyen Örgütler ( )

\section{8) Kuruluşun/Grubun karar alma süreçlerinde ne kadar etkilisiniz?}

1.Oldukça az ( ) 2.Az ( ) 3.Ne az ne fazla ( ) 4.Fazla( ) 5.Oldukça fazla ( )

9) Son bir ay içinde aşağıdaki boş vakit etkinliklerine kaç defa katıldınız?
1.Evde misafir ağırlamak ( )
7. Dışarıda akşam yemeği yemek ( )
2.Başkalarına misafirliğe gitmek ( )
8. Sinemaya gitmek ( )
3.Arkadaşlarla buluşmak ( )
9. Maça gitmek ( )
4.Siyaset tartışmak ( )
10. İnternette vakit geçirmek ( )
5.Herhangi bir hobiyle ilgilenmek ( )
11. Kitap okumak ( )
6.Konser, konferans, seminer vb. katılmak ( )
12. Seyahat etmek ( )

\section{Güven ve Dayanışma}

10) Genel olarak insanların çoğunun güvenilir olduğunu mu düşünürsünüz, yoksa ilişkilerinizde çok dikkatli olmayı mı tercih edersiniz?
1.Birçok insan güvenilirdir ( )
3.Bilmiyorum ( )
2. Bazı insanlar güvenilirdir ( )
4.Çok dikkatli olmak gerekir ( ) 
11. - 14. arasındaki ifadelere katılıp/katılmadığınızı belirtiniz.

\begin{tabular}{|l|l|l|l|l|l|l|}
\hline & \multicolumn{1}{|c|}{$\begin{array}{c}\text { Tamamen } \\
\text { Katılıyorum }\end{array}$} & Katılıyorum & Kararsızım & Katılmıyorum & $\begin{array}{c}\text { Kesinlikle } \\
\text { Katılmıyorum }\end{array}$ \\
\hline $\mathbf{1 1 )}$ & $\begin{array}{l}\text { Son 1 yıl içerisinde il / ilçede } \\
\text { güven seviyesi arttı. }\end{array}$ & & & & & \\
\hline 12) & $\begin{array}{l}\text { Hastalandığınız zaman } \\
\text { komşularınız size yardım eder. }\end{array}$ & & & & & \\
\hline 13) & $\begin{array}{l}\text { Maddi anlamda sıkıntı çeken } \\
\text { herhangi bir komşunuza } \\
\text { yardım edersiniz. }\end{array}$ & & & & & \\
\hline 14) & $\begin{array}{l}\text { Siz maddi anlamda sıkıntı } \\
\text { çektiğinizde çevrenizdeki } \\
\text { insanlardan yardım } \\
\text { alabilirsiniz. }\end{array}$ & & & & & \\
\hline
\end{tabular}

15)Sizin en çok güvendiğiniz kişiler kimlerdir?

\begin{tabular}{|l|l|c|c|c|c|c|}
\hline & & $\begin{array}{c}\text { Çok } \\
\text { Fazla (1) }\end{array}$ & $\begin{array}{c}\text { Oldukça } \\
\text { Fazla (2) }\end{array}$ & $\begin{array}{c}\text { Kararsızım } \\
\text { (3) }\end{array}$ & $\begin{array}{c}\text { Güvenmem } \\
\text { (4) }\end{array}$ & $\begin{array}{c}\text { Hiç Güvenmem } \\
\text { (5) }\end{array}$ \\
\hline $\mathbf{1}$ & Aileniz & & & & & \\
\hline $\mathbf{2}$ & Komşularınız & & & & & \\
\hline $\mathbf{3}$ & Tanıdığınız İnsanlar & & & & & \\
\hline $\mathbf{4}$ & Hemşerileriniz & & & & & \\
\hline $\mathbf{5}$ & Başka Dinden İnsanlar & & & & & \\
\hline $\mathbf{6}$ & Başka Milletten İnsanlar & & & & & \\
\hline $\mathbf{7}$ & i̇lk Defa Tanıştığınız İnsanlar & & & & & \\
\hline
\end{tabular}

16) Aşağıdaki kurumlardan hangilerine ne kadar güvenirsiniz?

\begin{tabular}{|c|c|c|c|c|c|c|c|}
\hline & \multicolumn{2}{|l|}{ Kurum } & $\begin{array}{c}\text { Çok Fazla } \\
\text { (1) }\end{array}$ & $\begin{array}{l}\text { Oldukça } \\
\text { Fazla (2) }\end{array}$ & $\begin{array}{c}\text { Kararsızım } \\
\text { (3) }\end{array}$ & $\begin{array}{c}\text { Güvenmem } \\
\text { (4) }\end{array}$ & $\begin{array}{c}\text { Hiç Güvenmem } \\
\text { (5) }\end{array}$ \\
\hline 1 & \multicolumn{2}{|l|}{ Hükümet } & & & & & \\
\hline \multirow{2}{*}{2} & \multirow{2}{*}{$\begin{array}{l}\text { Dini } \\
\text { Kurumlar }\end{array}$} & $\begin{array}{l}\text { Diyanet İşleri } \\
\text { Başkanlığı }\end{array}$ & & & & & \\
\hline & & $\begin{array}{l}\text { Cemaatler / } \\
\text { Tarikatlar }\end{array}$ & & & & & \\
\hline 3 & \multicolumn{2}{|c|}{ Silahlı Kuvvetler } & & & & & \\
\hline 4 & \multicolumn{2}{|c|}{ Sivil Toplum Örgütleri } & & & & & \\
\hline 5 & \multicolumn{2}{|c|}{ Adalet Kurumları } & & & & & \\
\hline 6 & \multicolumn{2}{|c|}{ Eğitim Kurumları } & & & & & \\
\hline 7 & \multicolumn{2}{|c|}{ Sosyal Güvenlik Kurumları } & & & & & \\
\hline 8 & \multicolumn{2}{|c|}{ Sağlık Kurumları } & & & & & \\
\hline 9 & \multicolumn{2}{|c|}{ Meslek Odası } & & & & & \\
\hline 10 & \multicolumn{2}{|c|}{ Basın Yayın Kurumları } & & & & & \\
\hline 11 & \multicolumn{2}{|c|}{ Millet Meclisi } & & & & & \\
\hline 12 & \multicolumn{2}{|l|}{ Polis } & & & & & \\
\hline 13 & \multicolumn{2}{|c|}{ Avrupa Birliği } & & & & & \\
\hline
\end{tabular}




\section{Kolektif Eylem ve İşbirliği}

17)Son bir yılda içinde toplumsal fayda olan herhangi bir aktiviteye katılıp diğer insanlarla birlikte çaIıştınız mı? (Telefon ve internet yardımları hariç).

\section{Evet ( ) 2. Hayır ( )}

18. - 21. arasındaki ifadelere katılıp/katılmadığınızı belirtiniz.

\begin{tabular}{|c|c|c|c|c|c|c|}
\hline & & $\begin{array}{c}\text { Tamamen } \\
\text { Katıllyorum }\end{array}$ & Katılıyorum & Kararsızım & Katılmıyorum & $\begin{array}{c}\text { Kesinlikle } \\
\text { Katılmıyorum }\end{array}$ \\
\hline 18) & $\begin{array}{l}\text { Toplumunuzdaki/ } \\
\text { çevrenizdeki insanlar } \\
\text { toplumsal aktivitelere } \\
\text { gönüllü bir biçimde } \\
\text { katııır veya yardımını } \\
\text { esirgemez. }\end{array}$ & & & & & \\
\hline 19) & $\begin{array}{l}\text { Eğer yaşadığınız } \\
\text { yerde bir okul sorunu } \\
\text { olsaydı, topluluktaki } \\
\text { insanlar çözüm } \\
\text { için birlikte hareket } \\
\text { ederlerdi. }\end{array}$ & & & & & \\
\hline 20) & $\begin{array}{l}\text { il/ilçedeki insanların } \\
\text { yüzde 50'den } \\
\text { fazlası ortak } \\
\text { kalkınma hedefleri } \\
\text { doğrultusunda } \\
\text { para ya da } \\
\text { zaman katkısında } \\
\text { bulunabilirler. }\end{array}$ & & & & & \\
\hline 21) & $\begin{array}{l}\text { İnsanlar } \\
\text { cezalandırılma ya da } \\
\text { eleştirilme kaygısı } \\
\text { olduğu için toplumsal } \\
\text { aktivitelere gönüllü } \\
\text { olarak katılır. }\end{array}$ & & & & & \\
\hline
\end{tabular}

\section{E. Bilgi ve Illetişim}

\section{2) Hangi sıklıkta radyo dinlersiniz?}
1. Her gün ( )
2. Haftada birkaç kez ( )
3. Haftada bir kez ( )
4. Ayda birkaç kez ( )
5. Hiç ( )

\section{3) Hangi sıklıkta televizyon izlersiniz?}
1. Her gün ( )
2. Haftada birkaç kez ( )
3. Haftada bir kez ( )
4. Ayda birkaç kez ( )
5. Hiç ( ) 
24) Hangi sıklıkla gazete okuyorsunuz?(İnternet dâhil)
1. Her gün ( )
2. Haftada birkaç kez ( )
3. Haftada bir kez ( )
4. Ayda birkaç kez ( )
5. Hiç ( )

25) En yakın postaneye varmak kaç dakikanızı alır?

1.15 dakikadan az ( ) 2.15-30 dakika ( ) 3.30-60 dakika ( ) 4. Bir saatten fazla ( )

26) En yakın internete ulaşmanız ne kadar sürenizi alır?

1.15 dakikadan az ( ) 2.15-30 dakika ( ) 3.30-60 dakika ( ) 4. Bir saatten fazla ( )

27) Sizce son 3 yıl içerisinde yaşadığınız il/ilçede “bilgiye ulaşım” nasıl gelişti?

$$
\text { 1.Gelişti ( ) 2.Geriledi ( ) 3.Değişmedi ( ) }
$$

28) Hükümetin neler yaptığı hakkında(tarımsal büyüme, çalışma refahı, aile planlaması, vb) üç temel bilgi kaynağınız nelerdir?(Lütfen en önemli 1 olacak şekilde üç tanesini numaralandırınız).
1.Akrabalar, arkadaşlar, komşular ( )
6.Gruplar ya da dernekler( )
2.Sivil toplum kuruluşları ( )
7.Iş ortağı ya da iş arkadaşlarından( )
3.Ulusal gazeteler ( )
8.Siyasi arkadaşlar ( )
4.Topluluk ya da yerel gazete ( )
9. Radyo( )
5.Internet ( )
10. Televizyon( )

\section{F. Sosyal Uyum ve Güdülenme}

29) Kendinizi ne kadar yaşadığınız şehrin bir parçası olarak görüyorsunuz?

1.Tamamen ( ) 2.Oldukça ( ) 3.Kısmen ( ) 4.Çok Az ( ) 5.Hiç Görmüyorum ( )

30) Sizin için yaşadığınız şehrin sosyal, ekonomik, kültürel, yaşam boyutları anlamında bir parçası oly mak ne kadar önemlidir?
1. Çok önemlidir ( )
2. Oldukça önemlidir ( )
3. Kısmen önemlidir ( )
4. Fazla önemli değil ( )
5. Hiç önemi yoktur ( )

31) Aynı muhitte yaşayan insanlar arasında gelir durumu, statü, etnik durum, din, politik inanç gibi nedenlerden kaynaklanan farklılıklar bulunabilir. Bu farklılıkları göz önünde bulundurduğunuzda yaşadığınız yerin farklılık düzeyi aşağıdakilerden hangisidir?
1. Büyük ölçüde farklı ( )
2. Oldukça farklı ( )
3. Ne farklı ne de benzer ( )
4. Benzer ( )
5. Oldukça benzer ( ) 
32) Bu farklılaşmanın herhangi bir probleme neden olabileceğini düşünüyor musunuz?

$$
\begin{array}{ll}
\text { 1. Evet ( ) 2. Hayır ( ) (34. soruya gidiniz) } & \text { 2 }
\end{array}
$$

33) Sizce aşağıdaki farklılaşmalardan hangi üçü problem yaratabilir? (Lütfen en önemli 1 olacak şekilde üç tanesini numaralandırınız).
1.Sosyal statü( )
6.Genç ve yaşlı kuşaklar arasındaki yaş farkı ( )
2.Eğitim( )
7.Cinsiyet( )
3.Mülk sahipliği( )
8.Maddi kaynaklara sahiplik( )
4.Dini inançlar( )
9.Etnik ya da dilsel farklılıklar( )
5.Politik görüşler( )
10.Diğer farklılıklar( )

34) Çeşitliliğe (farklılığa) tolerans gösterme açısından, aşağıdaki kişilere olan hoşgörünüzün boyutu nedir?

\begin{tabular}{|c|l|l|l|l|}
\hline & & Hoşgörülüyüm & Kararsızım & Hoşgörülü Değilim \\
\hline $\mathbf{1}$ & Sabıkalı insanlar & & & \\
\hline $\mathbf{2}$ & Uyuşturucu bağımlıları & & & \\
\hline $\mathbf{3}$ & Çok alkol kullananlar & & & \\
\hline $\mathbf{4}$ & AiDS hastası olanlar & & & \\
\hline $\mathbf{5}$ & Eşcinseller & & & \\
\hline $\mathbf{6}$ & Göçmenler & & & \\
\hline $\mathbf{7}$ & Farklı ırktan insanlar & & & \\
\hline $\mathbf{8}$ & Farklı mezhepten insanlar & & & \\
\hline $\mathbf{9}$ & Farklı dinden insanlar & & & \\
\hline
\end{tabular}

G. Güçlendirme ve Siyasi Eylem

35. - 42. arasındaki ifadelere katılıp/katılmadığınızı belirtiniz.

\begin{tabular}{|l|l|l|l|l|l|l|}
\hline $\mathbf{3 5}$ & $\begin{array}{c}\text { Tamamen } \\
\text { Katılıyorum }\end{array}$ & Katılıyorum & Kararsızım & Katılmıyorum & $\begin{array}{c}\text { Kesinlikle } \\
\text { Katılmıyorum }\end{array}$ \\
\hline $\begin{array}{l}\text { Acalışmalarından } \\
\text { memnunum. }\end{array}$ & & & & & \\
\hline $\mathbf{3 6}$ & $\begin{array}{l}\text { Aksaray'da hizmet } \\
\text { veren kamu } \\
\text { kurumlarının } \\
\text { kalitesinden } \\
\text { memnunum. }\end{array}$ & & & & & \\
\hline $\mathbf{3 7}$ & $\begin{array}{l}\text { Aksaray Belediyesi } \\
\text { hükümetten } \\
\text { bağımsız hizmet } \\
\text { getirebiliyor. }\end{array}$ & & & & & \\
\hline
\end{tabular}




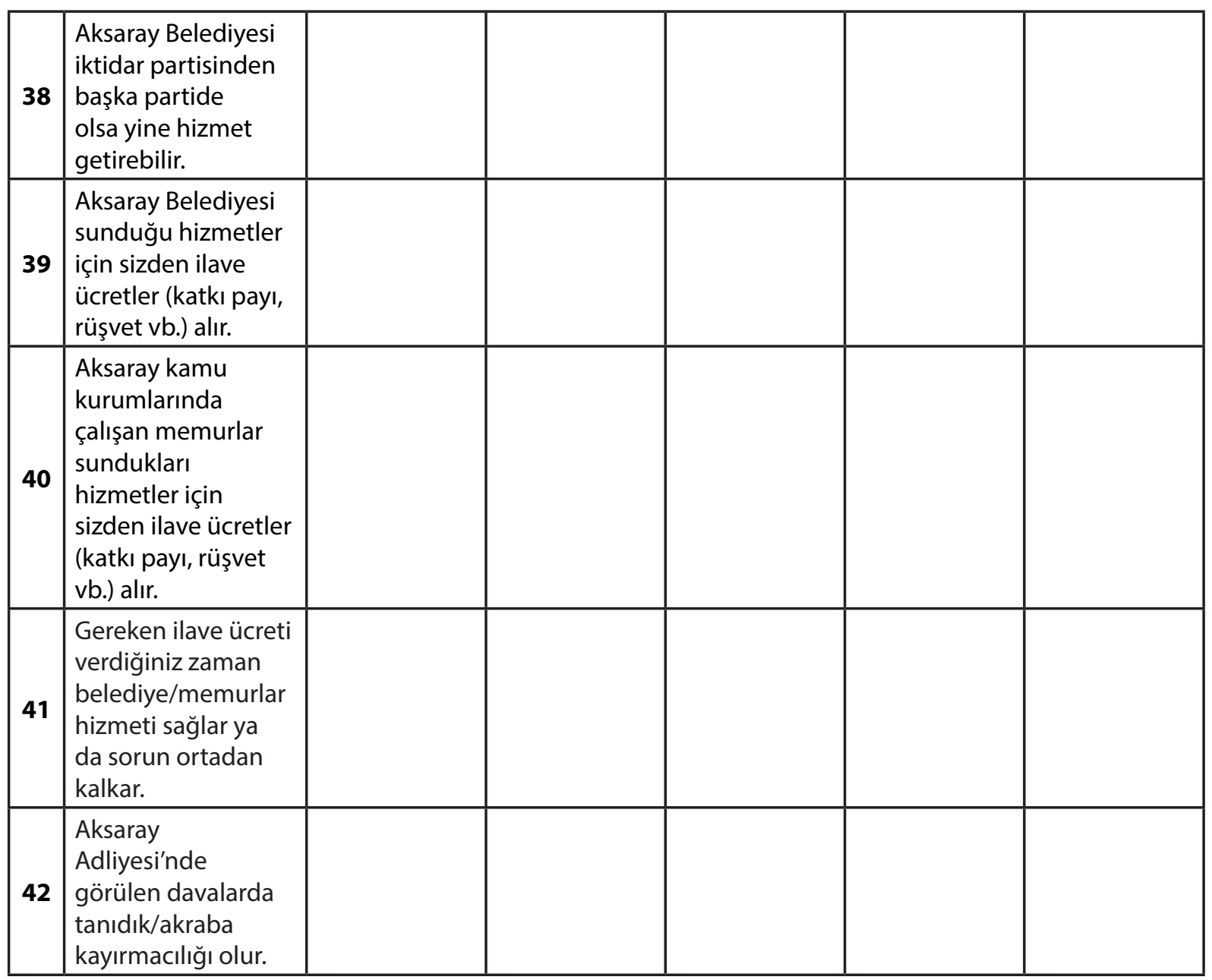

\section{3) Geçen 3 yıl içerisinde aşağıdaki siyasi etkinliklerden hangilerine katıldınız?}

\begin{tabular}{|c|l|l|l|}
\hline & Siyasi Etkinlik & Evet & Hayır \\
\hline $\mathbf{1}$ & Seçimlere Katılmak & & \\
\hline $\mathbf{2}$ & Kişisel Sorunlarla İlgili Dilekçe Yazmak & & \\
\hline $\mathbf{3}$ & Bir Politikacıya Mail Atmak/Mektup Yazmak & & \\
\hline $\mathbf{4}$ & Mahalledeki Sorunlarla Ilgili Dilekçe Yazmak & & \\
\hline $\mathbf{5}$ & Siyasi Parti Gençlik Kollarına Üye Olmak & & \\
\hline $\mathbf{6}$ & Siyasi Parti Kadın Kollarına Üye Olmak & & \\
\hline $\mathbf{7}$ & Toplu Yürüyüşe Katılmak & & \\
\hline $\mathbf{8}$ & Siyasi Partiye Üye Olmak & & \\
\hline $\mathbf{9}$ & Sivil Toplum Örgütüne Üye Olmak & & \\
\hline $\mathbf{1 0}$ & Boykot Eylemine Katılmak & & \\
\hline $\mathbf{1 1}$ & Internet Eylemine Katılmak & & \\
\hline $\mathbf{1 2}$ & Ev Ev Tanıtım Yapmak & & \\
\hline $\mathbf{1 3}$ & Broşür Dağıtmak & & \\
\hline
\end{tabular}


Ek - 3: ANOVA ve TUKEY Test Sonuçları

ANOVA Test Sonucu

\begin{tabular}{|l|c|c|c|c|c|}
\hline & $\begin{array}{c}\text { Kareler Toplamı } \\
\text { (Sum of squares) }\end{array}$ & $\begin{array}{c}\text { Serbestlik } \\
\text { Derecesi (df) }\end{array}$ & $\begin{array}{c}\text { Ortalama Kare } \\
\text { (Mean Square) }\end{array}$ & F Testi & $\begin{array}{c}\text { Anlamlılık } \\
\text { Düzeyi (Sig.) }\end{array}$ \\
\hline Gruplar Arası & 18,717 & 4 & 4,679 & 5,687 &, 000 \\
Gruplar İçi & 818,722 & 995 &, 823 & & \\
Toplam & 837,439 & 999 & & & \\
\hline
\end{tabular}

Kaynak: Yazarların hesaplamaları.

TUKEY HSD Test Sonucu

\begin{tabular}{|l|c|c|c|}
\hline \multirow{2}{*}{ Yerleşim Yeri } & \multirow{2}{*}{ Örneklem Sayısı (N) } & \multicolumn{2}{|c|}{$\begin{array}{c}\text { Alfa alt değeri=0,05 } \\
\text { (Subset for alpha=0,05) }\end{array}$} \\
\cline { 3 - 4 } & & 1 & 2 \\
\hline Güzelyurt & 62 & 1,2903 & \\
Ortaköy & 121 & 1,3802 & \\
Eskil & 81 & 1,4198 & 1,6375 \\
Merkez & 662 & 1,6375 & 1,8243 \\
Gülağaç & 74 & & \\
\hline
\end{tabular}

Kaynak: Yazarların hesaplamaları. 